\section{From health plan companies to international insurance companies: changes in the accumulation regime and repercussions on the healthcare system in Brazil}

\author{
Das empresas médicas às seguradoras \\ internacionais: mudanças no regime de \\ acumulação e repercussões sobre o \\ sistema de saúde no Brasil
}

De las empresas médicas a las aseguradoras internacionales: cambios en el régimen de acumulación y repercusiones sobre el sistema de salud en Brasil

\begin{abstract}
The concentration and internationalization of health plan companies in Brazil gave them a clearly financial face. Based on the need to understand the health care industry's capital accumulation patterns, the current study examines health plan companies' expansion strategies through the classification of their supply and demand characteristics by recent historical periods and an analysis of recent shareholding trends in one of the leading corporations in the Brazilian health care industry. The 1960s to 2000 s witnessed changes in the scale of demands for health plans and adherence by companies to long-term accumulation strategies. Beginning in the early 21st century, changes in the shareholding structures of the largest Brazilian company, consistent with the financialization of its accumulation regime, resulted in the rapid multiplication of its capital. Deepening segmentation of the health care system in a context marked by the downturn in the national economy challenges the preservation of public subsidies for private health plans.
\end{abstract}

Prepaid Health Plans; Health Systems; Technological Development; Innovation
Ligia Bahia 1

Mario Scheffer 2

Leandro Reis Tavares 3

Iale Falleiros Braga 4

\author{
${ }^{1}$ Faculdade de Medicina \\ Universidade Federal do \\ Rio de Janeiro, Rio de Janeiro, \\ Brasil. \\ 2 Universidade de São Paulo \\ São Paulo, Brasil. \\ 3 Instituto de Estudos em \\ Saúde Coletiva, Universidade \\ Federal do Rio de Janeiro, \\ Rio de Janeiro, Brasil. \\ 4 Escola Politécnica de Saúde \\ Joaquim Venâncio, Fundação \\ Oswaldo Cruz, Rio de Janeiro, \\ Brasil.
}

\author{
Correspondence \\ L. Bahia \\ Departamento de Medicina \\ Preventiva, Faculdade de \\ Medicina, Universidade \\ Federal do Rio de Janeiro. \\ Praça Jorge Machado \\ Moreira, Rio de Janeiro, RJ \\ 21941-590, Brasil. \\ ligiabahia@terra.com.br
}




\section{Introduction}

In the middle of the first decade of this century, health insurance and health plan companies in Brazil began to acquire a clearly financial appearance, and the presence of their representatives in government decision-making spheres became frequent and visible. The phenomenon is certainly not unique, and has links to the emergence of the post-Fordist regime, globalization of production, and widespread corporate reorganization in different national contexts 1 . The market concentration of companies in the health plan and health insurance industry is also not recent, having occurred in the 1990s in the United States 2. However, an analysis of specific results of the inclusion of private health insurance and health plan companies in Brazil's national health system is important for backing the discussion on tensions between the Brazilian Unified National Health System (SUS) and the private health plan industry.

The relations between health plan companies and financial sectors accompanied the persistent inflation accompanying financial activities in the 1990 s, as in various areas of Brazil's economy 3 . Health plan companies contributed subsequently to the expansion of financial ventures. Private equity funds established by independent fund managers led by investment banks and pension funds 4 and the launching of shares on the Stock Exchange allowed capitalization of the health plan companies 5 .

The literature on the origin and expansion of groups of health care professionals (nearly always physicians) shows different alternatives for marketing pre- and post-paid health care schemes, initially to employers and subsequently to individuals and families. The initial studies highlighted changes in the corporate structure and relations with government agencies in the first companies (1960-1980) 6,7. Later studies focused on examining the companies that remained active or were created simultaneously with the debates and early implementation of the SUS (1988-2000) 8,9,10. Although the literature highlights changes in the territorial scope and an increase in the number of policyholders 8 , what appears to characterize the current situation with health plans is the magnitude of the business, now ranking them among the top corporations in Brazil, besides their leaders' protagonist role in defining the health policy agenda.

Considering the need to analyze the relations between the expansion of the private health plan industry and national health policy, the current study examines the history of health plan companies in Brazil through the classification of their supply and demand characteristics by recent historical periods and an analysis of recent shareholding changes in one of the industry's largest corporations. The article thus centers on the systematization of shareholding structures and past political and institutional positioning and the analysis of a case that allows an approach to current accumulation strategies. The primary aim is to situate the current characteristics of health plan companies in relation to their historical background.

The study's main limitations relate to the difficulties in adjusting conceptual frames of reference elaborated for grasping economic processes and global contexts to understanding unique events and the heterogeneity of corporate groups acting in the health plan market. Other limitations result from the difficulties in obtaining data on the companies' shareholding structure. The combination of these two limitations objectively hinders an understanding of the processes involved in the expansion of health care privatization.

The initial effort at finding adequate frames of reference for examining changes in the accumulation regimes of health plan companies and the organization of an embryonic database does not allow answering the questions on the consequences (for the SUS) of the companies' affinity for financialization. This article merely raises the question, for more in-depth investigation in future studies.

\section{Methodological issues}

The study was based on theoretical contributions from the collective health area and recent analyses on national and international processes of financialization and financial dominance, especially those focusing on the effects of financial dominance of social policies. This is an exploratory study based on the literature and on systematization of data collected from government and corporate sources and in the commercial and academic media.

The study focuses primarily on the format of shareholding organization and processes of capital appreciation in health plan companies in two distinct political and economic circumstances: (1) the context that gave rise to health plan companies during Brazil's civilian-military dictatorship and (2) the first ten years of the implementation of the SUS. To depict the companies' characteristics in the two periods, considering supply, demand, and legislation, we drew on the concepts used by Donnangelo 11 for ownership/ owner and Cordeiro 7 for health plan companies 
and medical groups and other scientific publications, research reports, and a survey of pertinent official provisions, including tax legislation.

To describe the rapid changes in the group's corporate profile, we drew on the concepts of financializaton and accumulation regime. Financialization is a pattern of accumulation in which profits accrue mainly from financial channels, shaping an accumulation regime which, in the developed countries, results from the decline in profitability of productive activities, combined with credit expansion to protect consumption in the face of stagnation in real wage values 12 .

Corporate practices for approaching the finance-dominated accumulation regime include a wide range of strategies, such as: redistribution of profits and dividends among employees and shareholders; introduction of performance measures such as return on shares; mergers and acquisitions; and outsourcing 13 . The analysis did not include the relevant focus of studies on financialization, corporate behavior, and discursive construction, expressed in intentional management strategies to celebrate what are announced as positive financial acquisitions 14 . Although there is a study on changes in the discourses and values of executives in the health insurance industry 15 , its results would not be easily transposable to specific cases.

The criteria for selecting the Amil health plan company included its size in the industry and its position as one of Brazil's largest corporations, as well its adoption of financialization strategies discussed in the literature. In 2014, based on its asset value, Amil was classified as the largest health plan company in Brazil 16 and ranked 22nd among all Brazilian coporations 17. Its corporate expansion involved launching shares on the Stock Exchange, acquisitions, and an overture to foreign investors.

To retrace Amil's history, we consulted company balance sheets and reports, Stock Exchange reports, specialized publications, scientific studies, and media stories. Compilation of this material was painstaking but certainly not complete. The companies' records in the boards of trade are difficult to access, and the corporate reports are brief and generic, focused on publicity or exhibited as balance sheets, the interpretation of which requires expert knowledge. Therefore, the search for and expression of the information obtained thereby attempted to balance the need to confer scope and precision to the results, referenced on possible spinoffs for the health system rather than an assessment of the company's economic performance per se.

\section{Results}

The history of health plan/health insurance companies in Brazil can be divided into three cycles. The first is demarcated by relations between social security policies for the protection of skilled workers and the emergence of the first companies between the 1960s and 1980s. The second extended from the 1990s to the 2000s and was characterized by the marketing of company and individual health plans within the context of the implementation of the SUS. The most recent period has involved the presence of companies with international capital and which perform activities in financial intermediation.

Company health care policy agreements, established between the Social Security system and employers starting in 1965, seen as a stratagem by employers to decrease worker absenteeism due to illness, stimulated the emergence of two types of health plan companies: health maintenance organizations and medical cooperatives 7 . The former were shaped predominantly as not-forprofit organizations. Therefore, their legal status, although formally distinct, did not characterize them adequately. The main difference was the origin of the physicians (workers' health services, usually public hospitals, and professional bodies) and physicians' association with certified charitable hospitals.

The controversies surrounding the scope of the rights written into Brazil's 1988 Constitution 18 , objective difficulties with the implementation of the SUS 19, and indirect government incentives such as tax deductions and subsidies, as well as direct incentives such as financing of private plans for civil servants and employees of state-owned companies fostered the expansion of some pioneering companies as well as the entry of private hospital owners into the health plan market. In the early 1990s, the insurance companies, namely institutions from the financial industry, began acting in the health sector.

\section{From health plan companies to domestic corporate groups}

Tables 1 and 2 summarize the organizational supply and demand characteristics of health plans in the first two historical cycles. The main differences in corporate profile relate to the financing regime of demand and supply, acquisition or expansion of hospitals, and diversification of activities, although in the sphere of workers' benefits (e.g., meal vouchers) or credit, mainly benefiting physicians.

Company health care plans were signed simultaneously with the crackdown on political 
Table 1

Characteristics of health insurance and health plan companies in Brazil from the 1960s to the 1980s.

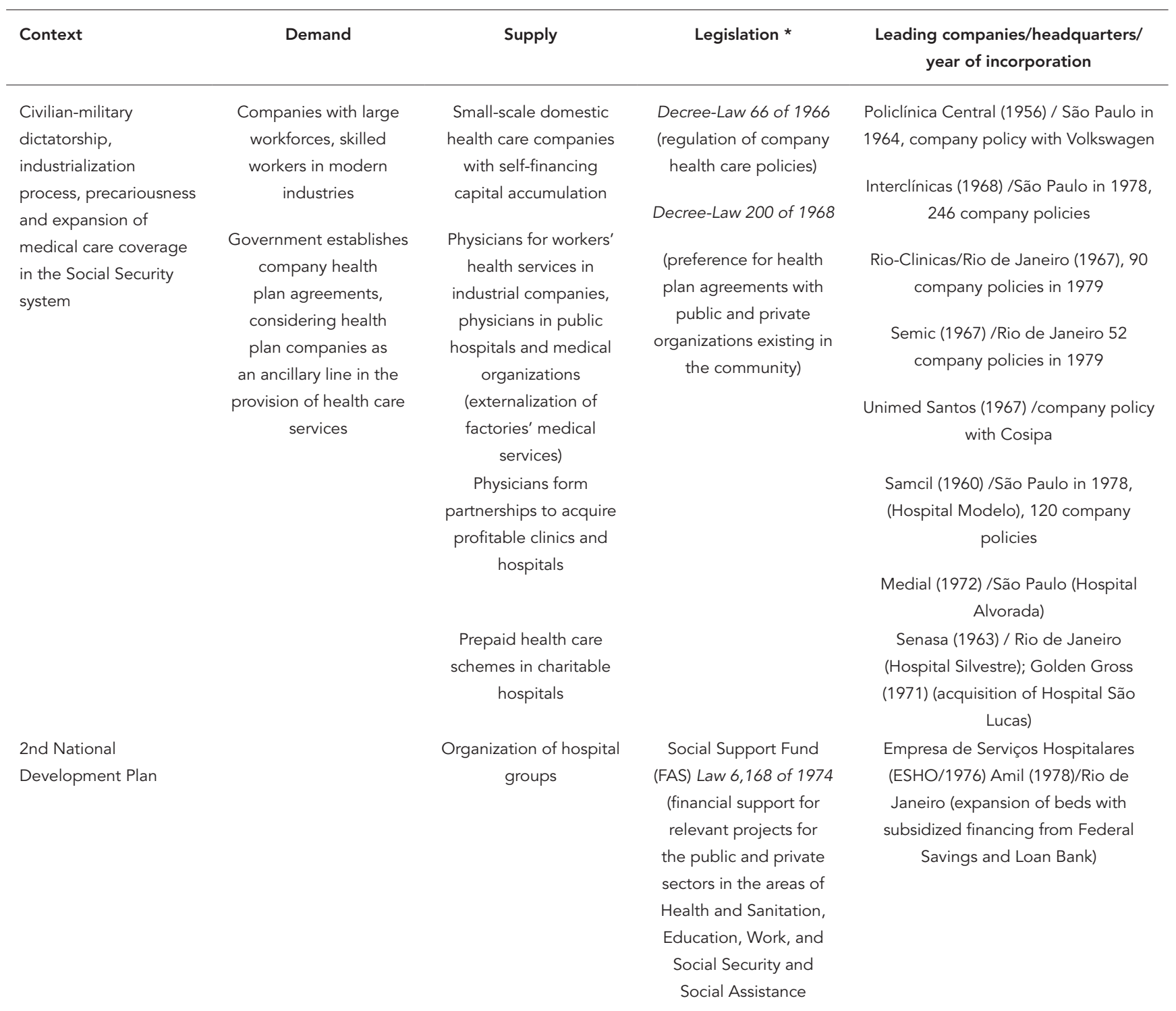

* Selected legislation (does not include all the legislation on the matter).

Sources: Câmara dos Deputados (Legislação. Pesquisa simplificada. http://www2.camara.leg.br/atividade-legislativa/legislacao, accessed on 14/Jul/2015); Secretaria da Receita Federal, Ministério da Fazenda (Legislação por assunto. http://www.receita.fazenda.gov.br/Legislacao/LegisAssunto/, accessed on 14/ Jul/2015); Cordeiro 7; Bahia et al. 43

and trade union participation, and they expressed a policy of dual transfer of Social Security attributes to the private sector: employers became responsible for the employees' health care and (especially those located in São Paulo and Rio de Janeiro) delegated this responsibility to health plan companies.

Owners of pioneering health plan companies provided consultancy on drafting the legislation for the privatization of social-security medical care 7. Specific policies for skilled workers, considered an asset to be stabilized 20 , aimed to respond to the negative perception of problems with access and quality in the medical care provided by the Social Security system, especially following unification of the country's retirement and pension institutes, and the conviction among administrators named by the civilianmilitary dictatorship concerning the inefficiency of public services 21 . 
Characteristics of health insurance and health plan companies in Brazil from the 1980s to 2000.

\begin{tabular}{|c|c|c|c|c|}
\hline Context & Demand & Supply & Legislation * & Acquisitions/Diversification \\
\hline $\begin{array}{l}\text { Re-democratization, } \\
\text { New Republic, oil crises, } \\
\text { rising interest rates, end } \\
\text { of continuous expansion } \\
\text { of the economy } \\
\text { Restrictions on } \\
\text { enforcement of } \\
\text { Constitutional principles } \\
\text { pertaining to Social } \\
\text { Security, Underfinancing } \\
\text { of the SUS }\end{array}$ & $\begin{array}{l}\text { Large-scale employers } \\
\text { (group plans) } \\
\text { Medium-sized } \\
\text { employers (group } \\
\text { plans) } \\
\text { Professional } \\
\text { associations/ } \\
\text { Trade unions } \\
\text { Middle-income } \\
\text { segments (individual } \\
\text { plans) }\end{array}$ & $\begin{array}{c}\text { Territorial expansion, } \\
\text { increase in client portfolios, } \\
\text { and associations of } \\
\text { pioneering companies } \\
\text { (health maintenance } \\
\text { organizations and } \\
\text { medical cooperatives), } \\
\text { diversification, acquisitions, } \\
\text { and corporate associations } \\
\text { Self-management } \\
\text { Initial activity by insurance } \\
\text { companies not affiliated } \\
\text { with banks } \\
\text { Domestic and international } \\
\text { investors } \\
\text { health plans }\end{array}$ & $\begin{array}{l}\text { Maintenance and granting of } \\
\text { charitable status to hospital } \\
\text { companies and health plans } \\
\text { Memorandum } 0051989 \text { of } \\
\text { the Inspectorate for Private } \\
\text { Insurance of the Ministry of } \\
\text { Finance, authorization for } \\
\text { insurance companies to pay } \\
\text { service providers directly } \\
\text { Consolidation of tax } \\
\text { exemptions and deductions, for } \\
\text { example: } \\
\text { partial reimbursement of private } \\
\text { plans or insurance } \\
\text { Law } 7,713 \text { of } 1988 \text { (tax write- } \\
\text { off for health care expenses } \\
\text { exceeding } 5 \% \text { of the taxpayer's } \\
\text { gross income) } \\
\text { servants through the SUS or } \\
\text { health plans, agreementh regulates } \\
\text { La, } 250 \text {, full write-off of }\end{array}$ & $\begin{array}{l}\text { Sergio Franco Laboratory } \\
\text { acquired by Golden Cross } \\
\text { and Amil (1983) } \\
\text { Acquisition of Golden Cross } \\
\text { by Cigna in } 1997 \\
\text { Meal voucher companies } \\
\text { Acquisition of mutual health } \\
\text { associations/ organization of } \\
\text { insurance companies } \\
\text { Organization of credit } \\
\text { cooperatives } \\
\text { Creation of holding } \\
\text { companies ** }\end{array}$ \\
\hline
\end{tabular}

SUS: Brazilian Unified National Health System.

* Selected legislation (does not include all the legislation on the matter);

** Companies with the controlling share of another company, or of a group of subsidiary companies.

Sources: Câmara dos Deputados (Legislação. Pesquisa simplificada. http://www2.camara.leg.br/atividade-legislativa/legislacao, accessed on 14/Jul/2015); Secretaria da Receita Federal, Ministério da Fazenda (Legislação por assunto. http://www.receita.fazenda.gov.br/Legislacao/LegisAssunto/, accessed on 14/ Jul/2015); Confederação Nacional das Empresas de Seguros Gerais, Previdência Privada e Vida, Saúde Suplementar e Capitalização (Normas do setor. http:// www.cnseg.org.br/cnseg/mercado/legislacao/normas-do-setor/, accessed on 30/Jul/2015).

The pioneering companies based their organization on self-financing and physicians' quotas and expanded their clientele through fixed (per capita) transfers from Social Security. They were created by physician-proprietors based on physical outpatient care structures or hospitals (the latter by the 1970s) 11. Many of these physicians were also salaried staff in various retirement and pension institutes and had to reorganize their professional affiliations due to the reduction in the number of employment relationships resulting from the unification of these institutes.

The clientele of the pioneering companies consisted exclusively of formal workers in companies from modern industries, and coverage often excluded their direct dependents. Although such company policies spread, they were not adopted by all employers. There were direct company-to-company "policies" without intermediation by the Social Security system, established through the retention of public funds earmarked 
for medical care, for the organization of the corporations' own medical care schemes 6 .

The 2nd National Development Plan (II PND), designed to give new direction to the country's development, prioritized an increase in the country's energy capacity and the production of basic inputs and capital goods, seeking to replace the previous model, which had prevailed during the period of the economic "miracle" of 1968-1973, whose priority was durable consumer goods. The repercussions of the premises of the II PND on health were contradictory. Brazilian Ministry of Health funds increased in relation to previous periods, and there were incentives for the creation of public institutional spaces for social policy planning and implementation of research projects 22 . However, subsidized loans from the Social Support Fund (FAS) financed the private hospital sector's installed capacity and leveraged health plan companies. One example of corporate expansion stimulated by government investments was the creation of Amil based on an original set of hospitals, quintupling the number of beds from 1974 to $1978{ }^{8}$.

Tensions between post-dictatorship re-democratization, the enactment of comprehensive social rights by the 1988 Constitution, and pressure for fiscal adjustment and curtailment of government spending in the context of a slowdown in economic growth hindered the implementation of the constitutionally mandated SUS, among other consequences. The second oil price boom, the decision by the United States in 1979 to increase interest rates and close the financial market to indebted countries, and the growing hegemony of neoliberal thinking in the international arena 23 reopened the debate on the state's role and public policies in Brazil.

The adjustment program under the Administration of President Collor, whose term began in 1990, followed the three principles: privatization, deregulation, and liberalization of prices and wages. President Collor's inaugural address was explicit: "The state should be ready, permanently ready, to guarantee access by low-income people to certain vital goods. It should provide access to housing, food, health, education, and public transportation for all those who depend on it (...)" 24 .

Criticism of the inefficiency of public services 25 , rationing of access, and quality problems in the public health care system 26 fueled the supply of health plans and insurance and demands by workers' organizations, including those representing civil servants, to continue and extend private coverage schemes.

During the so-called lost decades 27, the demands for health plans and insurance extended from large corporations to medium-sized companies and further to associations and unions of civil servants and liberal professionals and families and individuals from higher income segments. The growth and diversification of activities of health plan companies attracted domestic investors and investments and some international insurance companies. Still, the predominance of domestic capital was preserved. The experience of the acquisition of Golden Cross by the American company Cigna was not successful, leading to losses of more than US $\$ 400$ million due to the Brazilian company's problems with the accumulation of tax debts and legal disputes 28 .

The legislation stimulated the expansion of private health plans and insurance. With regard to demand incentives, the direct transfer of public funds to companies (characteristic of the first cycle) was replaced by indirect subsidies and payment of plans for government employees. That is, the mobilization of fiscal policies combined with administrative provisions and the inclusion of spending on private plans in the government budgets. On the supply side, the main rulings focused on the reduction of tax rates or tax exemptions on the Services Tax (ISS) ${ }^{29}$, contributions like the Employees' Profit Participation Program/Public Service Employee Savings Program (PIS-PASEP) and Tax for Social Security Financing (COFINS) 30, and equal treatment for insurance companies in relation to commercial plan companies, vis-à-vis the relationship with the health services network.

The adoption of long-term loans from stateowned banks for charitable and private hospitals 15 defined the profile of a sector with a mature capitalist format. In the late 1990s, various health plan companies began to congregate corporate groups, and the insurance companies not only entered the health care market, but also presented themselves in it as relevant interlocutors in the formulation of regulatory policies in the process of debates and approval of Law 9.656 of 199831. The changes in the scale of operations of health plan companies enabled them to mediate the relations between the demand and health service providers in different conditions from those prevailing in the accumulation regime based on self-financing.

\section{Brazilian corporate groups in the finance-dominated accumulation regime: the example of Amil}

The early 21st century witnessed renewed hopes for the recovery of growth and new linkage between social and economic policies for an inclusive development model. There was evidence 
that that the basic macroeconomic conditions for sustained expansion had been reestablished. The increase in formal employment and improved income distribution signaled the recovery of Brazil's industrial capacity and prospects for generating endogenous technical progress 32 and social welfare.

However, the systemic crisis that struck in the late 2000s imposed fiscal requirements and pushed away the functions of energizing effective demand and productive profits, while economic policies became essential vectors for the macroeconomic reproduction of financial wealth 33 . Therefore, gains in access to (and use of) health care provided by the SUS were not limited to the growth of the private sector, a process that included competition for public human and financial resources 34 .

Policies for the expansion of consumption energized not only the low-income credit segment, but also the marketing of health plans to income classes C and D, the so-called "new middle class" 35 or "emerging middle class" 36 . In 2010, the Caixa Econômica Federal (Federal Savings and Loan Bank) announced the possibility of selling health insurance to economic classes $\mathrm{C}$ and $\mathrm{D}$ 37. And in 2013, according to polls conducted by Meireles 38, among the persons covered by private health plans, shorter policy coverage time was associated with lower income.

The history of Amil from 2002 until its sale to the American corporation UnitedHealth suggests that its adherence to capitalization via acquisitions was a strategy that both preceded and remained in force after it launched part of its capital on the Stock Exchange (Table 3).

Despite the shareholding changes, family control of Amil was maintained. The change in the company's accumulation regime, including launching part of its capital on the market and the acquisitions, increased the company's worth. From 2007 to 2012, the number of clients in the group's flagship company, Amil Assistência Médica Internacional, increased from $1,222,617$ to $3,496,77435$. However, its capital expansion was considerably superior to the increase in the number of policies. In 2012, when Amil was purchased by UnitedHealth, the company was assessed at R\$ 10 billion or US\$ 6.4 billion, the payment corresponding to $60 \%$ of the controlling shareholders' capital and RS 3.4 billion for the shares on the Stock Exchange (Bovespa) 36 .

Table 4 shows the values involved in the acquisition of Amil by UnitedHealth, evidencing the rapid appreciation of the Brazilian group's capital, as measured both by the increase in the nominal share value and especially in the multi- plication of the company's capital both in Brazilian currency and U.S. dollars.

Amil is now a company with foreign capital. Its former owner still heads the health business in Brazil. The family that organized Amil holds the majority share of seven hospitals, including Hospital 9 de Julho in São Paulo, Hospital de Clinicas in Niterói, and Casa de Saúde Santa Lúcia in Rio de Janeiro, among others, and DASA. The family also retains the position of CEO and Chairman of the Management Board of Amil until 2017 and became the largest individual shareholder in UnitedHealth.

Contrary to the history of other health plan corporate groups, including some acquired by Amil itself, changes in the company's formal shareholding structure did not include the removal of the former owners from action in its health business. Its main leader and founder's influence even appears to have expanded, as witnessed by his presence in the meeting of the so-called "Brazilian GDP" group with the Minister of Finance 39. Although assessments on the success or failure of financialization are beyond the scope of this paper, it appears plausible that the company's capital appreciation has opened select political channels to the corporate group.

\section{Discussion}

The concentration and recent internationalization of health plan companies, as evidenced by the Amil story, allows different interpretations. In the more conventional sense, the health plan and insurance industry is highly concentrated. In July 2015, Amil operated $7.5 \%$ of all medical care policies in Brazil. From a regional perspective, $62.5 \%$ of the companies had their headquarters in the Southeast region of Brazil 40. Ranking third, the industry can be seen as regressive or concentrated from the angle of the clients' income. There is a positive association between family income and private health policy coverage. In 2008 , only $2.6 \%$ of Brazilians in the income bracket below one minimum wage had private health plans, compared to $4.8 \%$ in the 1 to 2 minimum wage bracket, $9.4 \%$ in the 2 to 3 minimum wage bracket, $18 \%$ in the 3 to 5 minimum wage bracket, $34.7 \%$ in the bracket earning 5 to 10 times the minimum wage, and $76 \%$ among those earning 20 times the minimum wage or more (Agência Nacional de Saúde Suplementar. Informações detalhadas ANS tabnet. http://www.ans.gov.br/ anstabnet/, accessed on 14/Jul/2015).

Internationalization of Brazilian health plan companies actually preceded authorization by Law 9,656 of 1998. Likewise, the investment by 
Table 3

History of the Amil Group from 2002 to 2013 *.

\begin{tabular}{|c|c|c|c|}
\hline Year & Acquisitions and mergers/ other investments & Years & Acquisitions and mergers/ other investments \\
\hline $\begin{array}{l}2002- \\
2003\end{array}$ & $\begin{array}{l}\text { Amico São Paulo, health maintenance organization with } 300 \\
\text { thousand clients, and creation of Dix-Amico }\end{array}$ & 2009 & $\begin{array}{l}\text { Medial, health maintenance organization with } 1.4 \text { million } \\
\text { clients. Purchase value } \\
\qquad R \$ 1.2 \text { billion } \\
\text { Hospital } 9 \text { de Julho (São Paulo) }\end{array}$ \\
\hline \multirow[t]{3}{*}{2006} & $\begin{array}{l}\text { Purchase of health insurance policyholder portfolio (42 } \\
\text { thousand clients) from Porto Seguro Saúde }\end{array}$ & 2010 & $\begin{array}{l}\text { Hospital Pro-Cardiaco Rio de Janeiro } \\
\text { Hospital Samaritano Rio de Janeiro }\end{array}$ \\
\hline & $\begin{array}{l}\text { Semic Rio de Janeiro, founded in } 1967 \text {, health maintenance } \\
\text { organization with some } 100 \text { thousand clients }\end{array}$ & & $\begin{array}{l}\text { Excelsior Pernambuco, health maintenance organization with } \\
\qquad 132 \text { thousand clients. }\end{array}$ \\
\hline & & & $\begin{array}{c}\text { Purchase of ESHO by AmilPar } \\
\text { Association between Dasa (Diagnósticos da América } \\
\text { S.A.), clinical laboratory company and Md1 Diagnósticos, } \\
\text { specialized in imaging technologies, associated with Amil. } \\
\text { Dasa (Diagnósticos da América) control of } 26 \% \text { of the shares } \\
\text { by the Amilpar controlling }\end{array}$ \\
\hline \multirow[t]{4}{*}{2007} & $\begin{array}{c}\text { Clinihauer, Paraná, founded in 1969, with } 120 \text { thousand } \\
\text { clients including Hospital Milton Muricy and the Cendilab } \\
\text { laboratory network }\end{array}$ & 2011 & $\begin{array}{l}\text { Control of Lincx (health plan company in São Paulo) by Amil } \\
\text { Assistência Médica } \\
\text { UN Diagnósticos Ltda by ESHO }\end{array}$ \\
\hline & $\begin{array}{l}\text { MedCard São Paulo 61,200 clients including } 1 \text { hospital and } \\
\qquad 2 \text { clinics }\end{array}$ & & Hospital Pasteur (Rio de Janeiro) by ESHO \\
\hline & $\begin{array}{l}\text { Blue Life São Paulo, } 150 \text { thousand clients } \\
\text { Life System São Paulo } 55 \text { thousand clients. }\end{array}$ & & Casa de Saude Santa Lucia S.A by ESHO \\
\hline & $\begin{array}{l}\text { Sale of Farmalife to Drograsmil (drugstore chain in Rio de } \\
\text { Janeiro) }\end{array}$ & & \\
\hline \multirow[t]{2}{*}{2007} & $\begin{array}{l}\text { Public launch of shares on the São Paulo Stock Exchange } \\
\text { (Bovespa) (IPO **) }\end{array}$ & 2012 & UnitedHealth Group acquires Amil \\
\hline & Shareholding restructuring of Amil Participshares S.A. & & $\begin{array}{c}\text { Participation by Amil in the Hospitals Group (HPP) of Caixa } \\
\text { de Seguros de Portugal (HPP) }\end{array}$ \\
\hline \multirow[t]{4}{*}{2008} & Ampla (Sistema Ipiranga), São Paulo, 29 thousand clients & 2013 & Delisting from Bovespa \\
\hline & Casa de Saúde Santa Lúcia, Rio de Janeiro & & Delisting of Amil's capital from Bovespa \\
\hline & Hospital de Clinicas SK Steckelberg Ltda, Brasília & & $(\mathrm{APO} * \star \star)$ \\
\hline & & & $\begin{array}{l}\text { The offering was listed by the American company } \\
\text { UnitedHealth, which announced its purchase of the } \\
\text { controlling share of Amil in October } 2012\end{array}$ \\
\hline
\end{tabular}

APO: acquisition public offering; IPO: initial public offering.

* Compilation based on various sources, possibly incomplete;

** Is the event that signals the first offer of a company's shares, i.e., when it publically lists its capital and begins to sell its shares on the Securities Exchange. When companies go public, they transfer part of their shareholding control to investors. In exchange,

publically traded companies receive money for their investments;

*** The APO often precedes the company's "delisting". Purchase of shares on the market can be done by the company itself, by controlling shareholders, or by new controllers (when the company whose shares are being purchased is the object of acquisition).

Sources: Herzlinger \& Pinho 44; Portal Fator Brasil 45; BM\&FBovespa 46; AmilPar 47; Exame 48. 
Purchase and sale values for Amil's shares and Amil Group's capital.

\begin{tabular}{|c|c|c|c|c|c|}
\hline Year & Purchase and sale & Object of acquisition & Controller & Value in R\$ & Value in US\$ \\
\hline 2007 & $\begin{array}{c}\text { Listing of Amil shares on the } \\
\text { Bovespa exchange (share value } \mathrm{R} \$ \\
\text { 14.00) adjusted share } \\
\text { value ( } \$ \text { 19.07) * }\end{array}$ & $\begin{array}{l}\text { Shares represent } 27.8 \% \text { of } \\
\text { Amil's capital }\end{array}$ & Amil & $\mathrm{R} \$ 1.218$ billion & 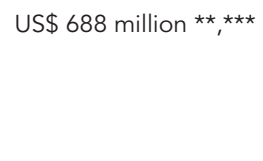 \\
\hline 2012 & $\begin{array}{l}\text { Acquisition of controlling share of } \\
\text { Amil by UnitedHealth }\end{array}$ & $\begin{array}{l}58.9 \% \text { of the capital of the } \\
\text { Amilpar controlling group }\end{array}$ & UnitedHealth & $\mathrm{R} \$ 6.4$ billion & 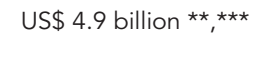 \\
\hline 2013 & Delisting (share value $\mathrm{R} \$ 31.80$ ) & $\begin{array}{l}\text { Purchase of Amil shares } \\
\text { on the Bovespa exchange, } \\
\text { representing } 25.5 \% \text { of } \\
\text { Amil's capital }\end{array}$ & UnitedHealth & $\mathrm{R} \$ 2.878$ billion & US\$ 1.225 billion \\
\hline
\end{tabular}

* Currency exchange, Banco Central: calculation of adjusted consumer prices index for month December 2013;

** Currency exchange, Banco Central: US\$ conversion on 31 December 2007;

$\star \star \star$ Value announced by the companies.

Sources: Valor Econômico 39; BM\&FBovespa 46; AmilPar 49.

domestic and international funds in hospital and diagnostic laboratory networks preceded the legislation that allowed participation by foreign capital in health care activities, under Law 13,097 of 2015. Still, operations of the size involved in the acquisition of Amil required backing by the legislation and approval by the Federal Attorney General's Office, suggesting that the legal provisions and their interpretations were relevant for ensuring reliability in the eyes of foreign investors. The mismatch between corporate internationalization practices and the legislation suggests complacency by public authorities in the face of strategies that anticipated changes in the capitalization rules.

The finance-dominated accumulation regime of health plan companies in Brazil differs from that in the United States. While Amil launched shares on the Stock Exchange and remained under the strict control of its founding owners, the UnitedHealth Group has no defined controller, its capital is considered pulverized, and the corporate group's administration is professionalized 41. The Amil purchase involved acquisitions of UnitedHealth shares by Amil's exprincipal owner, paradoxically making him the largest individual shareholder and only foreigner to sit on the board of directors of the largest corporate group in the United States health plan and information industry 42 . The preservation of own- ership control suggests the non-implementation of strategies involving redistribution of profits and dividends among workers, including health care professionals and small individual investors.

Although the expansion of health plan and health insurance companies has occurred even in economic cycles with lower growth, a slowdown in investments in the sector is possible. In 2012, international investors like Stephen Hemsley, President and CEO of UnitedHealth, had optimistic expectations.

"Brazil has emerged as a growing market with consistent evolution in health plans and services. The country's growing economy, rising middleclass, and policies stimulating the managed care sector make it a market with high potential for growth" 41.

However, part of this prediction failed to play out. The economic recession looming on the horizon since President Rousseff was sworn in for her second term in January 2015 limited the market's expansion. Therefore, the public policies supporting privatization, including those stimulating financialization, were reedited and renewed, occupying a central role on the public agenda.

The conceptual references from reflections on financialization and accumulation help shed light on the shareholding restructuring processes in the health plan industry. A relative 
separation was seen between the capital appreciation of a company that markets health plans and the number of its clients. However, this observation does not allows inferences on other economic groups or companies in the industry, or even on each company in the Amil group itself, since there was no detailed description of each company's performance, including those involved in health care provision such as hospitals and diagnostic laboratories.

\section{Final remarks}

Brazil has participated in the history of financialization of capitalism since its beginning, due to its important demands for credit and its position as an emerging power, made possible by high interest rates with high returns. Thus, Brazil's participation in the world economy imposed a financial rationality on a portion of the domestic business sector and fueled the domestic rent-seeking sectors. Health plan companies consolidated in the late 20 th century became a platform for financial investments in the early 21 st century.

The evidence of the importance of public policies for the expansion of different accumulation regimes in health plan companies (selffinancing, dependent on the scale of intermediation operations between supply and demand for medical and hospital care, and financialization) is well-known even to foreign investors. The mismatch between the growth of health plans and the overall economy can be explained by two factors. The first, more widespread, is the population's desire for guaranteed access to (and use of) health services. The second, less studied, concerns the set of legal provisions supporting the private sector and the views by government officials on the inevitability and even virtuosity of the health system's segmentation in Brazil.

The attempt to open the black box of the financial area of an industry focused on health care is a considerable challenge and involves scrutinizing international financial spaces, examining the internal logic of adherence to financialization strategies, mapping tensions and conflicts between stakeholders, and understanding the origin and course of policies that provide the backdrop for markets, especially to avoid interpretations based on abstract predictions.

Thus, this effort to systematize part of the phenomenon that affects Brazilian companies working in the health care industry is not conclusive. Despite attempts to overcome conceptual and methodological gaps, imprecisions resulting from the sources of information and a mixture of approaches necessarily make this a provisional descriptive study, while its principal merit has been to identify avenues for further investigation. 


\section{Contributors}

L. Bahia, M. Scheffer, L. R. Tavares and I. F. Braga participated in all stages of the study's elaboration.

\section{Acknowledgments}

To the Brazilian National Research Council (CNPq Research Project 405077/2013-0).

\section{References}

1. Arrighi G. A ilusão do desenvolvimento. Petrópolis: Editora Vozes; 1997.

2. Austin AD, Hungerford TL. The market structure of the health insurance industry. Washington DC: Congressional Research Service; 2009. (CRS Report for Congress).

3. Paulani LM. A crise do regime de acumulação com dominância da valorização financeira no Brasil. Estud Av 2009; 23:25-39.

4. Grün R. A dominação financeira no Brasil contemporâneo. Tempo Social 2013; 25:179-213.

5. Bahia L. Financeirização da assistência médico hospitalar no governo Lula. In: Machado CV, Baptista TWF, Lima LL, organizadores. Políticas de saúde no Brasil: continuidades e mudanças. 22a Ed. Rio de Janeiro: Editora Fiocruz; 2012. p. 91-116.

6. Giffoni MR. Assistência médica e as relações de trabalho na empresa: o modelo de convênio com a Previdência Social [Dissertação de Mestrado]. São Paulo: Departamento de Ciências Sociais, Faculdade de Filosofia, Letras e Ciências Humanas, Universidade de São Paulo; 1981.

7. Cordeiro H. As empresas médicas: as transformações capitalistas na prática médica. Rio de Janeiro: Edições Graal; 1984.

8. Bahia B. Planos e seguros de saúde: padrões e mudanças nas relações entre o público e o privado [Tese de Doutorado]. Rio de Janeiro: Escola Nacional de Saúde Pública, Fundação Oswaldo Cruz; 1999.
9. Andreazzi MFS. Teias e tramas: relações públicoprivadas no setor saúde brasileiro dos anos 90 [Tese de Doutorado]. Rio de Janeiro: Instituto de Medicina Social, Universidade do Estado do Rio de Janeiro; 2002.

10. Duarte CMR. Modelo organizacional da Unimed: estudo de caso sobre medicina suplementar [Tese de Doutorado]. Rio de Janeiro: Escola Nacional de Saúde Pública, Fundação Oswaldo Cruz; 2003.

11. Donnangelo MCF. Medicina e sociedade: o médico e seu mercado de trabalho. São Paulo: Pioneira; 1975.

12. Boyer R. A teoria da regulação: uma análise crítica. São Paulo: Editora Nobel; 1990.

13. van der Zwan N. Making sense of financialization. Socioecon Rev 2014; 12:99-129.

14. Froud J, Haslam C, Joahl S, Williams K. Shareholder value and financialization: consultancy promises, management moves. Econ Soc 2000; 29:80-110.

15. Braga IF. Entidades empresariais e a política nacional de saúde - da cultura de crise à cultura da colaboração [Tese de Doutorado]. Rio de Janeiro: Escola Nacional de Saúde Pública Sergio Arouca, Fundação Oswaldo Cruz; 2009.

16. 1000 maiores empresas e as campeãs em 25 setores e 5 regiões. Valor 1000 2015; Edição 2015.

17. Maiores \& melhores: as 1000 maiores empresas. Exame 2015; Edição 109202. 
18. Vianna LJW. A democracia e os três poderes no Brasil. Belo Horizonte: Editora da UFMG/Rio de Janeiro: Instituto Universitário de Pesquisas do Rio de Janeiro/Fundação de Apoio à Pesquisa do Estado do Rio de Janeiro; 2002.

19. Paim JS. A Constituição Cidadã e os 25 anos do Sistema Único de Saúde (SUS). Cad Saúde Pública 2013; 9:1927-36.

20. Salm CL, Fogaça A. Tecnologia, emprego e qualificação: algumas lições do século XIX. Revista de Economia Contemporânea 1998; 4:107-35.

21. Entrevista com José Dias Corrêa Sobrinho [fita cassete]. Rio de Janeiro: Núcleo de História Oral, Casa de Oswaldo Cruz; 1986.

22. Escorel S. A reviravolta na saúde: origem e articulação do movimento sanitário. Rio de Janeiro: Editora Fiocruz; 2009.

23. Bielschowsky R, Mussi C. Políticas para a retomada do crescimento: reflexões de economistas brasileiros. Brasília: Instituto de Pesquisa Econômica Aplicada/Comissão Econômica para a América Latina e o Caribe; 2002.

24. Collor de Mello F. Discurso de posse no Congresso Nacional. http://www.biblioteca.presi dencia.gov.br/ex-presidentes/fernando-collor/ discursos-1/1990/103.pdf/view (accessed on 14/Jul/2015).

25. Anderson P. El papel de las ideias en la construcción de alternativas. Argentina: Consejo Latinoamericano de Ciencias Sociales; 2004.

26. Paim J, Travassos CMR, Almeida C, Bahia L, Macinko J. The Brazilian health system: history, advances, and challenges. Lancet 2011; 377:1778-97.

27. Bielschowsky R. Sesenta años de la CEPAL: textos seleccionados del decenio 1998-2008. Buenos Aires: Siglo Veintiuno Editores; 2010.

28. Rosemburg C. Prêmio Caro. Exame 2000; (719). http:/ / exame.abril.com.br/revista-exame/edi coes/719/noticias/premio-caro-m0048220.

29. Supremo Tribunal Federal. Recurso Especial REsp 642810 MG 2004/0051890-0 (STJ). http:// www.jusbrasil.com.br/jurisprudencia/busca? $\mathrm{q}=\mathrm{RE}+115.308+\mathrm{RJ}$ (acessado em 20/Ago/2015)

30. Brasil. Medida Provisória no 2.158-35, de 24 de agosto de 2001. Altera a legislação das Contribuições para a Seguridade Social - COFINS, para os Programas de Integração Social e de Formação do Patrimônio do Servidor Público - PIS/PASEP e do Imposto sobre a Renda, e dá outras providências. Diário Oficial da União 2001; 27 ago.

31. Scheffer M. Os planos de saúde nos tribunais: uma análise das ações judiciais movidas por clientes de planos de saúde, relacionadas à negação de coberturas assistenciais no Estado de São Paulo [Dissertação de Mestrado]. São Paulo: Faculdade de Medicina, Universidade de São Paulo; 2006.

32. Quadros WJ. 2009 a 2012: heterodoxia impulsiona melhorias sociais. Campinas: Instituto de Economia, Universidade Estadual de Campinas; 2014.

33. Braga C. Crise sistêmica da financeirização e a incerteza das mudanças. Estud Av 2009; 23:89-102.

34. Marten R, McIntyre D, Travassos C, Shishkin S, Longde W, Reddy S, et al. An assessment of progress towards universal health coverage in Brazil, Russia, India, China, and South Africa (BRICS). Lancet 2014; 384:2164-71.
35. Meirelles R. Desejos e aspirações dos consumidores dos planos de saúde. In: Anais do 18o Congresso Brasileiro dos Corretores de Seguros. http://www.fenacor.com.br/xviiicongresso/apre sentacoes/desejos-aspiracoes-renato-meirelles. pdf (accessed on 11/Jul/2015).

36. PricewaterhouseCoopers. O mercado de serviços de saúde no Brasil. http://www.pwc.com.br/pt/ publicacoes/setores-atividade/assets/saude/heal thcare-port.pdf (accessed on 04/Aug/2015).

37. Villela F. Caixa estuda possibilidade de oferecer planos de saúde para população de menor renda. http://agencia-brasil.jusbrasil.com.br/noticias/2157995/caixa-estuda-possibilidade-de-ofe recer-planos-de-saude-para-populacao-de-me nor-renda (accessed on 11/Jul/2015).

38. Meireles R. Percepção dos brasileiros em 2012. http:// docplayer.com.br/9249546-Data-popu lar-saude-na-nova-classe-media-brasileira-re nato-meirelles-renato-datapopular-com-br.html (accessed on 18/Aug/2015).

39. UnitedHealth fecha capital da Amil em operação de R\$ 2,9 bilhões. http://www.valor.com.br/em presas/3097594/united-health-fecha-capital-da -amil-em-operacao-de-r-29-bilhoes (accessed on 18/Aug/2015).

40. Instituto Brasileiro de Geografia e Estatística. Um panorama da saúde no Brasil: acesso e utilização dos serviços, condições de saúde e fatores de risco e proteção á saúde: 2008. Rio de Janeiro: Instituto Brasileiro de Geografia e Estatística; 2010.

41. UnitedHealth Group. UnitedHealth group facts Q2, 2015. http://www.unitedhealthgroup.com/ / media/UHG/PDF/About/UNH-Fact-Book.ashx (accessed on 14/Jul/2015).

42. Faria N. UnitedHealth fecha acordo para adquirir controle da Amil. http://www.infomoney.com.br/ minhas-financas/planos-saude/noticia/2579526/ unitedhealth-fecha-acordo-para-adquirir-contro le-amil (accessed on 11/Jul/2015).

43. Bahia L, Antunes LR, Cunha TCA, Martins WS. Planos de saúde no Brasil: origens e trajetórias. Relatório de pesquisa. Rio de Janeiro: Universidade Federal do Rio de Janeiro; 2005.

44. Herzlinger RE, Pinho RR. Amil and the Health Care System in Brazil. Boston: Harvard Business School; 2011. (Harvard Business School Case, 312-029).

45. Portal Fator Brasil. Amil par: receita cresce $32 \%$ e Ebit da dobra em 2007. http://www.revistafatorbrasil.com.br/ver_noticia.php?not=33537 (acessed on 30/Jul/2015).

46. BM\&FBovespa. Pregões anteriores, 2015. http:// www.bmfbovespa.com.br/fechamento-pregao/ BuscarUltimosPregoes.aspx?idioma=pt-br (accessed on 18/Aug/2015)

47. Amil Par. Relatório anual de sustentabilidade, 2012. Rio de Janeiro: Amil Par; 2012.

48. Amil compra grupo hospitalar português por $€$ 85,6 mil. http://exame.abril.com.br/negocios/no ticias/amil-compra-grupo-hospitalar-portuguespor-85-6-mi-de-euros (acessado em 14/Jul/2015).

49. Amil Par. Anúncio de início de oferta pública de distribuição primária e secundária de ações ordinárias de emissão, 2007. http://www.bmfbovespa. com.br/pt-br/mercados/download/Amil-Anuncio -Inicio-12112007.pdf (accessed on 18/Aug/2015). 


\section{Resumo}

A concentração e internacionalização de empresas de planos de saúde no Brasil conferiram-lhes feição financeira. Considerando a necessidade de compreender os padrões de acumulação desse setor, o trabalho examina estratégias de expansão das empresas de planos de saúde por meio da periodização de atributos da oferta e demanda e exame da trajetória patrimonial recente de um dos grandes grupos do setor. Entre os anos 1960 e 2000, ocorreram alterações na escala das demandas por planos de saúde e adesão das empresas a estratégias de acumulação de longo prazo. A partir do século XXI, as alterações nas estruturas societárias da maior empresa brasileira, compatíveis com o regime de acumulação financeirizada, resultaram na multiplicação de seu capital em um curto intervalo de tempo. O aprofundamento da segmentação do sistema de saúde, em um contexto marcado pela desaceleração da economia, questiona a preservação dos subsídios públicos para os planos privados.

Planos de Pré-Pagamento em Saúde; Sistemas de Saúde; Desenvolvimento Tecnológico; Inovação

\section{Resumen}

La concentración e internacionalización de empresas de planes de salud en Brasil les han conferido un carácter financiero. Considerando la necesidad de comprender los padrones de acumulación de ese sector, el trabajo examina estrategias de expansión de las empresas de planes de salud, mediante la periodización de atributos de oferta y demanda y el examen de la trayectoria patrimonial reciente de uno de los grandes grupos del sector. Entre los años 1960 y 2000, se produjeron alteraciones en la escala de las demandas por parte de planes de salud y una adhesión de las empresas a estrategias de acumulación a largo plazo. A partir del siglo XXI, las alteraciones en las estructuras societarias de la mayor empresa brasileña, compatibles con el régimen de acumulación de carácter financiero, resultaron en la multiplicación de su capital en un corto intervalo de tiempo. La profundización de la segmentación del sistema de salud, en un contexto marcado por la desaceleración de la economía, cuestiona la preservación de los subsidios públicos para los planes privados.

Planes de Salud de Prepago; Sistemas de Salud; Desarrollo Tecnológico; Innovación
Submitted on 19/Sep/2015

Final version resubmitted on $07 /$ Dec/2015 Approved on 09/Dec/2015 